\title{
Characterisation of the Wetting Behaviour of Poor Wetting Food Powders and the Influence of Temperature and Film Formation ${ }^{\dagger}$
}

\author{
John J. Fitzpatrick ${ }^{1 *}$, Justine Salmon ${ }^{1}$, Junfu $\mathbf{J i}^{2}$ and Song Miao ${ }^{2}$ \\ ${ }^{1}$ Process \& Chemical Engineering, School of Engineering, University College Cork, Ireland \\ ${ }^{2}$ Teagasc Food Research Centre, Moorepark, Ireland
}

\begin{abstract}
Characterisation of the wettability of five poor wetting food powders was performed using static immersion and contact angle measurements. The effect of temperature $\left(20,50\right.$ and $\left.70{ }^{\circ} \mathrm{C}\right)$ on wettability showed varying effects on the powders. Higher temperatures majorly improved the wettability of chocolate and high fat powders but worsened the wettability of sodium caseinate and milk protein isolate. Rate-limiting regime testing was performed by pouring a fixed mass of powder on to the surface of water in an agitated beaker and visually assessing what was rate-limiting rehydration after 1 minute. The rate limiting regime tended to be floating at lower agitation speeds and dispersed clumps of varying sizes at higher speeds. However, there were major differences observed between the powders. Some of the powders formed strong films at powder/water interfaces, that could act as a barrier to water penetration and wettability. Consequently, force displacement testing was performed on a layer of powder on the water surface to assess the strength of any powder film formed. Some of the powders formed strong films that may in-part explain their poor wetting behaviour and their propensity to form strong clumps that were difficult to disrupt.
\end{abstract}

Keywords: food powders, rehydration, wettability, clumping, film/skin strength

\section{Introduction}

Ease of rehydration is a very important functional property of food powders (Schubert, 1993), as many food powders eventually end up being rehydrated. Powders that rehydrate easily and are not problematic are essential for industrial users and home consumers. Some food powders rehydrate easily while others are more difficult (Barbosa-Canovas et al., 2005). Consequently, a good understanding of rehydration behaviour is necessary along with a knowledge of the factors that influence poor rehydration behaviour.

Rehydration has a number of steps, but it can be broadly broken down into wetting, where the powder is initially contacted with water to wet the powder particles, followed by solubilisation where the powder particles disperse and dissolve in water. It is desirable that both these steps occur rapidly and completely, however some powders may prove difficult to wet and/or solubilise.

Received 24 June 2016; Accepted 19 August 2016

Western Road, Cork, Ireland

Teagasc, Fermoy, Co. Cork P61 C996, Ireland

* Corresponding author: John J. Fitzpatrick;

E-mail: j.fitzpatrick@ucc.ie

TEL: +353-21-4903089
There are many factors that can influence the wettability of a powder. Poor wetting powders tend to float on the surface of still water and sink very slowly into water. Powder particle surface composition will influence powder hydrophobicity, and this will influence wetting behaviour with water. Powder formation, for example by spray drying, may influence powder properties that influence rehydration (Gaiani et al., 2010). Porowska et al. (2015) showed that spray drying parameters and feed composition can be manipulated to influence the surface composition which can influence wetting behaviour.

Powder physical properties, such as particle size, densities, porosity and morphology, can influence wetting behaviour. Powders with higher densities tend to sink more rapidly. Powders with larger particle size tend to have better wetting behaviour because water can penetrate more easily into the larger void spaces between the particles. Consequently, granulation is commonly used to improve the wettability of powders, however slimy skin or film formation at the powder/water interface may impede water penetration into the bulk powder (Ji et al., 2016).

The wetting process can be made more difficult by the formation of powder clumps by some poor wetting powders, as these clumps need to be broken down (BarbosaCanovas et al., 2005). Clumps may form where skins or 
fidms decur at the water/powder interface which can inhibit water penetration into the powder clump. Agitation helps improve sinking, clump disruption and dispersion of powder particles. Many food powders are rehydrated in tanks that are mechanically agitated. The tank configuration, agitator type used and mechanical power intensity coupled with water temperature and its conductivity may all impact on rehydration behaviour (Richard et al., 2013; Jeantet et al., 2010; Schober and Fitzpatrick, 2005; Fitzpatrick and Cuthbert, 2004).

The wettability of powders has been assessed using a variety of techniques, including the International Dairy Federation standard method (IDF, 1979), the Washburn method (Washburn, 1921), dynamic contact angle measurement (Dupas et al., 2013) and the turbidity method (Gaiani et al., 2007, 2009). Food powder rehydration may be complex in nature, and quantitative techniques may not fully capture this complexity. Powders may float on the surface for prolonged periods of time; they may settle and form sediments at the bottom of the vessel; they may disperse as clumps that prove difficult to disrupt. Consequently, Mitchell et al. (2015) described a qualitative approach to help provide further insight into describing and understanding powder rehydration. They describe a rate-limiting regime mapping approach that qualitatively describes the particular aspect or regime that limits the overall rehydration in a stirred vessel at a specific condition of agitation.

The focus of this paper is on poor wetting powders. In particular, it examines factors that influence poor wetting behaviour, investigates the influence of temperature and agitation on the wetting, clumping and dispersion behaviour of poor wetting powders, and investigates clumping and the strength of skins formed at powder water interfaces.

\section{Materials and methods}

\subsection{Powders and their composition}

Five poor wetting powders and one easy wetting powder were tested and compared and these are presented in Table 1. Skim milk, $73 \%$ high fat milk, milk protein isolate (MPI) and sodium caseinate powders were obtained from dairy powder manufacturers in Ireland, and chocolate and wheat flour powders were purchased in a local supermarket. The composition data provided in Table 1 were obtained from product packaging or dairy powder manufacturer data, except for the water content which was measured by an oven drying test $\left(102{ }^{\circ} \mathrm{C}\right.$ for 24 hours).
Table 1 Powders and their \% composition

\begin{tabular}{lccccc}
\hline powder & protein & fat & $\begin{array}{c}\text { carbo- } \\
\text { hydrate }\end{array}$ & water & ash \\
\hline Skim milk & 35 & 1 & 52 & 4.8 & 7 \\
Chocolate & 6.3 & 6 & 75 & 2.9 & 0.9 \\
High fat & 9 & 73 & 13 & 2 & 3 \\
Caseinate & 85 & 1.3 & 1.3 & 8.8 & 4 \\
MPI & 86 & 1.5 & 0.5 & 7.4 & 6 \\
Flour & 10 & 1.3 & 76 & 11.8 & 0.8 \\
\hline
\end{tabular}

Table 2 Powder particle size and densities

\begin{tabular}{lcccc}
\hline powder & $\begin{array}{c}\text { particle } \\
\text { size } \\
\text { (microns) }\end{array}$ & $\begin{array}{c}\text { apparent } \\
\text { density }\end{array}$ & $\begin{array}{c}\text { poured } \\
\mathrm{BD}^{1} \\
\left(\mathrm{~kg} \mathrm{~m}^{-3}\right)\end{array}$ & $\begin{array}{c}\text { tapped } \\
\mathrm{BD}^{1}\end{array}$ \\
\hline Skim milk & 132 & 1220 & 490 & 548 \\
Chocolate & 109 & 1530 & 638 & 722 \\
High fat & 76 & 934 & 280 & 433 \\
Caseinate & 90 & 1310 & 500 & 620 \\
MPI & 50 & 809 & 291 & 387 \\
Flour & 85 & 1490 & 590 & 729 \\
\hline
\end{tabular}

${ }^{1}$ bulk density

\subsection{Powder particle size and densities}

The median $\left(d_{50}\right)$ of a volume particle size distribution, particle apparent density, poured and tapped bulk densities were measured, as described by Fitzpatrick et al. (2016), and these data are provided in Table 2.

\subsection{Wettability}

The method used was an extension of the International Dairy Federation (IDF) method (IDF, 1979), and is described by Fitzpatrick et al (2016). The method essentially measures the time for a given mass of powder to sink beneath the water surface, and this time is referred to as the wetting time. Powders having a wetting time less than 1 minute can be considered as easy wetting powders and powders having wetting times greater than 5 minutes can be considered as poor wetting powders. The temperature of the water was maintained at either 20,50 or $70^{\circ} \mathrm{C}$. Poor wetting powders may take very long time to wet or may not totally wet. To overcome this time limitation, the $\%$ wettability was evaluated as defined in equation 1 . This consisted of measuring the amount of powder that disappeared from the water surface after 60 minutes, as described by Fitzpatrick et al. (2016).

$$
\% \text { Wettability }=100 \times \frac{\text { mass of powder disappeared }}{\text { mass of initial powder }}
$$


al $\partial^{\circ}$

dethis pawder if less than 60 minutes, and the \% wettability at 60 minutes for those powders whose wetting time was greater than 60 minutes. This represents an improved approach for assessing and comparing the wettability of poor wetting powders.

\subsection{Rate-limiting regime mapping}

This is a similar method to that described by Fitzpatrick et al. (2016) and is based on that reported by Mitchell et al. (2015). A $2 \mathrm{~L}$ glass beaker with a diameter of $125 \mathrm{~mm}$ was filled with $1600 \mathrm{~mL}$ of water, as illustrated in Fig. 1a. An agitator with a four-bladed pitch-blade impeller was inserted axially into the water at a fixed location and was operated at speeds between 100 to $750 \mathrm{rpm}$. Little or no vortex formation occurred at speeds up to $300 \mathrm{rpm}$. At $400 \mathrm{rpm}$ and higher, a vortex formed and deepened progressively with higher speed, as illustrated in Fig. 1b, engaging the impeller at around $750 \mathrm{rpm}$.

The water was heated to the required temperatures $(20$, 50 and $\left.70^{\circ} \mathrm{C}\right)$ using a hotplate. 16 grams of powder $(1 \% \mathrm{w} / \mathrm{v})$ was weighed and emptied into the agitated water. The rehydration was visually observed and a qualitative evaluation of any rate-limitation(s) to achieving complete dispersion or dissolution was made at the end of the first minute. Key words were used to describe any rate-limitations, such as sedimentation (if powder remained on the bottom of the beaker); floating (if powder remained floating on the surface of the water); and clumps in dispersion (if powder formed clumps that were visible in the dispersion). The procedure was carried out in duplicate for each powder.

\subsection{Film strength at powder water interface}

A force-displacement test was used to measure the strength of films developed at the powder/water interface. $110 \mathrm{~g}$ of water was filled into a small glass beaker with internal diameter and height of $65 \mathrm{~mm}$ and $40 \mathrm{~mm}$, respectively. Powder was sieved onto the water surface until it filled the beaker giving a powder thickness of $7 \mathrm{~mm}$. Excess powder was removed to produce a smooth surface. A $35 \mathrm{~mm}$ plunger was then centered and moved axially through the powder at a constant speed of $0.08 \mathrm{~mm} / \mathrm{s}$, as illustrated in Fig. 2, and force vs displacement was measured using a TA HD Plus Texture Analyser (Stable Microsystems, UK). With no powder present the forcedisplacement through water is illustrated in Fig. 3a. Powders displaying measurable film strength showed behavior similar to that illustrated in Fig. 3b with a noticeable peak. This is the peak force required for the plunger to penetrate through the film and was used as an index of film strength. Powders displaying negligible film strength

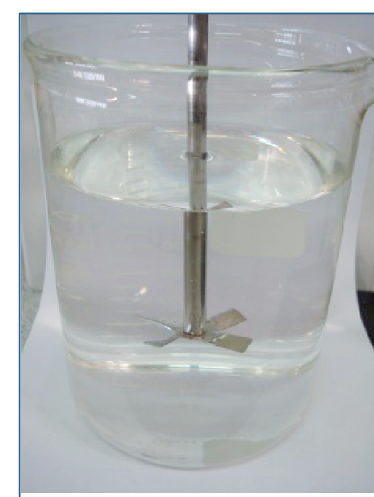

(a) Still

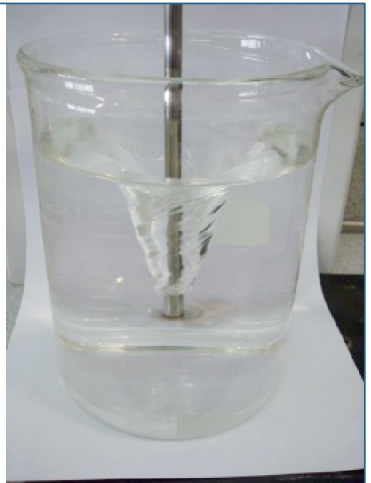

(b) $700 \mathrm{rpm}$
Fig. 1 Rate-limiting regime mapping: (a) beaker and agitator; (b) agitation at $600 \mathrm{rpm}$, deep vortex.

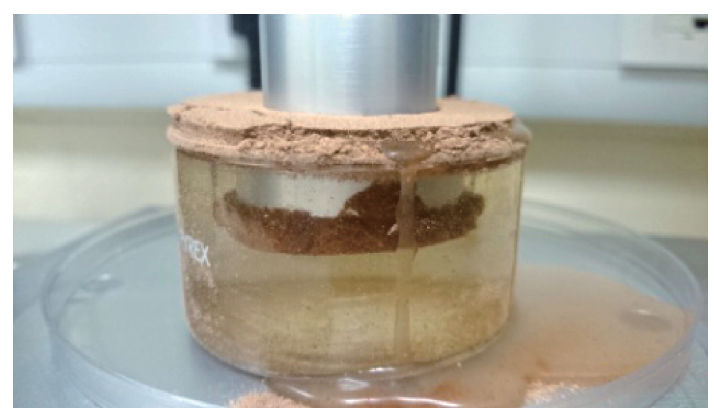

Fig. 2 Plunger moving axially through chocolate powder $\left(1 \mathrm{~min}, 20^{\circ} \mathrm{C}\right)$.
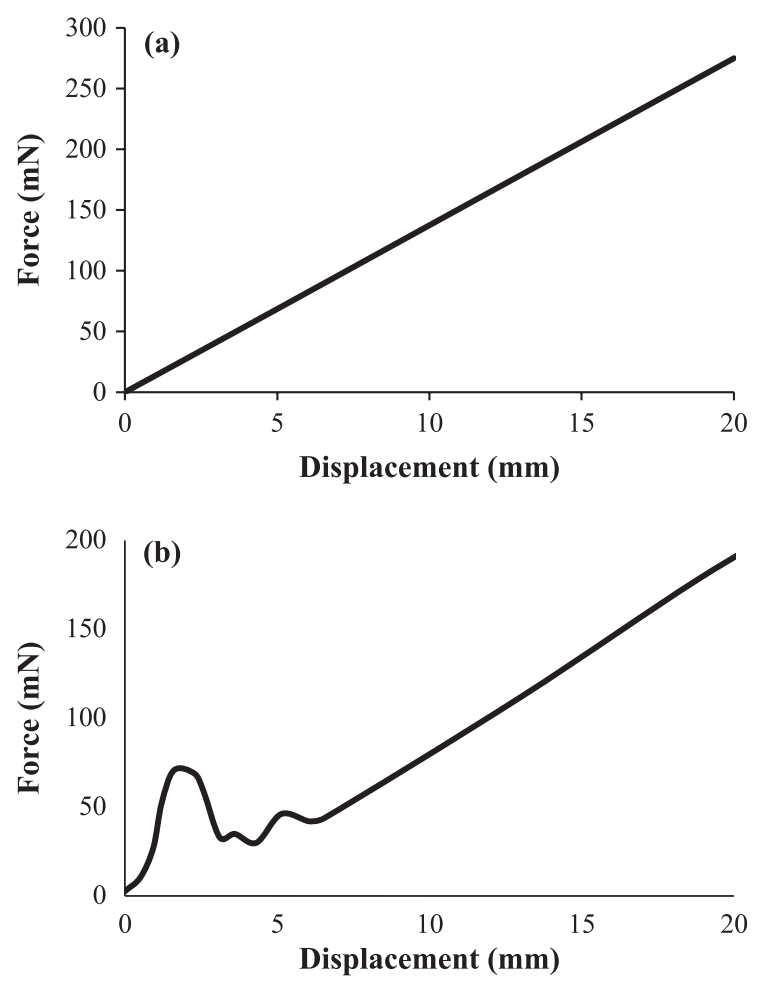

Fig. 3 Force displacement: (a) water; (b) SMP $\left(1 \mathrm{~min}, 20^{\circ} \mathrm{C}\right)$. 
dosplayed a similar linear behavior to that illustrated in Fig. 3a. Measurements were conducted at water temperatures of 20,50 and $70{ }^{\circ} \mathrm{C}$ and powder water contact times of 1 and 20 minutes.

\section{Results and discussion}

\subsection{Wettability and effect of temperature}

Results from wettability testing are presented in Tables 3 and 4, along with contact angle data presented in Table 5. The poor wetting powders, except for the wheat flour, had contact angles greater than 90 degrees. Hydrophobic surfaces tend to be the major determinant of high contact angles, and surface chemistry and composition determine hydrophobicity. Consequently, bulk composition, which influences surface composition, is having a major impact on the wettability of the powders. The wettability results were closely related to the contact angle data, except for the SMP and wheat flour where the flour had a lower contact angle than the SMP even though it had a longer wetting time.

At $20^{\circ} \mathrm{C}$, the high fat powder had very poor wettability at only $5 \%$ after 60 minutes, where it essentially floated on the water surface. This is most likely due to the hydrophobic nature of fat and its low apparent density, which is lower than the density of water. The chocolate powder is poor wetting, displaying $50 \%$ wettability after 60 minutes. Its poor wettability is most likely due to its composition, in particular a significant fat content of $5.9 \%$, giving rise to a hydrophobic surface, as evidenced by its contact angle data. Its particle size and densities were not unusually low and should not be contributing to its poor wettability. The high milk protein powders, sodium caseinate and MPI, were both poor wetting powders, having poorer wettability than the chocolate powder. Both powders displayed high contact angles, and this is most likely due to their composition. Consequently, their high protein contents, being derived mainly from caseins, were mainly responsible for the poor wettability of these powders. Crowley et al. (2015) showed how composition influenced the contact angle of milk protein concentrate powders, with higher protein (lower lactose) content resulting in higher contact angles. The low apparent density and relatively small particle size of the MPI powder may also contribute to its poor wettability.

The effect of temperature on wettability is presented in Tables 3 and 4. For the easy wetting SMP with a wetting time less than 1 minute, wettability improved with increasing temperature. However, temperature displayed differing impacts on the poor wetting powders. Increasing temperature had a very beneficial impact on the chocolate powder. Likewise, for the high fat powder, where at 50
Table 3 Powder wetting times

\begin{tabular}{lccc}
\hline powder & $20{ }^{\circ} \mathrm{C}$ & $50{ }^{\circ} \mathrm{C}$ & $70{ }^{\circ} \mathrm{C}$ \\
\hline Skim milk & $51 \mathrm{~s}$ & $16 \mathrm{~s}$ & $10 \mathrm{~s}$ \\
Chocolate & $>1 \mathrm{~h}$ & $2 \mathrm{~min}$ & $1.2 \mathrm{~min}$ \\
High fat & $>1 \mathrm{~h}$ & $3 \mathrm{~min}$ & $1 \mathrm{~min}$ \\
Caseinate & $>1 \mathrm{~h}$ & $>1 \mathrm{~h}$ & $>1 \mathrm{~h}$ \\
MPI & $>1 \mathrm{~h}$ & $>1 \mathrm{~h}$ & $>1 \mathrm{~h}$ \\
Flour & $31 \mathrm{~min}$ & $13 \mathrm{~min}$ & $>1 \mathrm{~h}$ \\
\hline
\end{tabular}

Table $4 \%$ Wettability of poor wetting powders after 60 minutes

\begin{tabular}{lccc}
\hline powder & $20{ }^{\circ} \mathrm{C}$ & $50{ }^{\circ} \mathrm{C}$ & $70{ }^{\circ} \mathrm{C}$ \\
\hline Chocolate & 50 & 100 & 100 \\
High fat & 5 & 100 & 100 \\
Caseinate & 27 & 15 & 15 \\
MPI & 22 & 16 & 18 \\
Flour & 100 & 100 & 73 \\
\hline
\end{tabular}

and $70{ }^{\circ} \mathrm{C}$ the powder sank just below the surface, wetted and formed a layer due to the lower density of fat. The greatly improved wetting behaviour may be related to the fact that milk fats melt in the range of -40 to $37^{\circ} \mathrm{C}$ (McCarthy, 2006).

Increasing temperature did not improve the wettability of the caseinate and MPI powders; in fact the wettability disimproved as shown in Table 4. Both of these powders are high protein powders containing caseins which are thermally resistant in the experimental range and the caseins appear to be maintaining their surface hydrophobicity and poor wettability. The flour powder displayed a different behavior with an optimum wetting temperature somewhere between 20 and $70{ }^{\circ} \mathrm{C}$. Increasing temperature from 20 to $50{ }^{\circ} \mathrm{C}$ showed improved wettability but increasing further to $70^{\circ} \mathrm{C}$ showed a wettability that was worse than at $20^{\circ} \mathrm{C}$. The reduced wettability at $70{ }^{\circ} \mathrm{C}$ is most likely due to the effect of temperature on the gelatinisation of starch which occurs typically in the range of 53 to $64{ }^{\circ} \mathrm{C}$ for wheat flours (Fennema, 1985) and the interaction between starch and wheat proteins which can form films when heated (Potter, 1986).

\subsection{Rate-limiting regime mapping}

Rate-limiting regime mapping tests were undertaken to visually investigate the effect of agitation and temperature on the wetting, sinking, clumping and dispersion of the powders. For SMP, the rate limiting regime at low agitation (200 rpm and less) was sedimentation at $20^{\circ} \mathrm{C}$. Dispersed clumps were observed at 300 and $400 \mathrm{rpm}$ agi- 
tation speeds, however the powder was well dispersed at $500 \mathrm{rpm}$ and higher. Sedimentation was less rate-limiting at higher temperature, but dispersed clumps were still observed up to $400 \mathrm{rpm}$. Clumping is most likely due to the presence on the particle surface of fat and some types of proteins that make the surface less hydrophilic. Furthermore, fat and proteins often concentrate to the surface in spray dried powders. Kim et al. (2002) showed the surface fat content was much higher than the bulk value in spray dried dairy powders.

The rate-limiting regime map of the chocolate powder is presented in Table 6. The dominant rate-limitation at $20^{\circ} \mathrm{C}$ was floating, most likely due to the significant fat content. Increasing temperature had a major effect on the chocolate powder with it being well dispersed by $300 \mathrm{rpm}$ at both 50 and $70^{\circ} \mathrm{C}$. The high fat powder essentially floated on the surface of the water up to $300 \mathrm{rpm}$ at $20^{\circ} \mathrm{C}$, as illustrated Fig. 4a. This could be expected due to its inherently hydrophobic nature and its low apparent density. At $400 \mathrm{rpm}$ and greater, a stronger and stronger vortex formed and more powder was drawn into dispersion as fine clumps. However, Fig. 4b shows many powder clumps still circulating in the vortex, although these became less and less at higher speeds, but some were still

Table 5 Contact angle formed between deionized water $\left(20^{\circ} \mathrm{C}\right)$ and powder surface over a 10 second period

\begin{tabular}{lcccc}
\hline \multicolumn{1}{c}{ powder } & $1 \mathrm{~s}$ & $2 \mathrm{~s}$ & $5 \mathrm{~s}$ & $10 \mathrm{~s}$ \\
\hline Skim milk & 82 & 60 & 58 & 58 \\
Chocolate & 104 & 94 & 91 & 86 \\
High fat & 104 & 103 & 102 & 98 \\
Caseinate & 130 & 130 & 130 & 129 \\
MPI & 150 & 145 & 142 & 137 \\
Flour & 38 & 30 & 25 & 21 \\
\hline
\end{tabular}

Table 6 Rate-limiting regime map for chocolate powder

\begin{tabular}{|c|c|c|c|}
\hline $\begin{array}{l}\text { Speed } \\
(\mathrm{rpm})\end{array}$ & $20{ }^{\circ} \mathrm{C}$ & $50{ }^{\circ} \mathrm{C}$ & $70{ }^{\circ} \mathrm{C}$ \\
\hline 100 & \multirow{7}{*}{$\begin{array}{c}\text { floating } \\
\text { (decreased } \\
\text { with agitation) }\end{array}$} & $\begin{array}{l}\text { some floating }+ \\
\text { sedimentation }\end{array}$ & $\begin{array}{l}\text { some floating }+ \\
\text { sedimentation }\end{array}$ \\
\hline 200 & & $\begin{array}{c}\text { light } \\
\text { sedimentation }\end{array}$ & $\begin{array}{c}\text { light } \\
\text { sedimentation }\end{array}$ \\
\hline 300 & & \multirow{6}{*}{ well-dispersed } & \multirow{6}{*}{ well-dispersed } \\
\hline 400 & & & \\
\hline 500 & & & \\
\hline 600 & & & \\
\hline 700 & & & \\
\hline 750 & well-dispersed & & \\
\hline
\end{tabular}

present at $750 \mathrm{rpm}$ along with fine clumps in dispersion. Increased temperature had a major effect by reducing the floating limitation and increasing dispersion, as illustrated by comparing Fig. 4a \& c.

Floating was the dominant rate-limiting regime for both the MPI and sodium caseinate powders at $20^{\circ} \mathrm{C}$, most likely due to their high casein protein content, as both powders have low fat contents. The MPI powder behaved somewhat similar to the high fat and chocolate powders in the sense that increased dispersion occurred at higher speeds and complete dispersion was only achieved at the highest speed of $750 \mathrm{rpm}$. Temperature did not appear to significantly influence the regime map of MPI, and the rehydration behaviour appeared similar at all three temperatures.

The rate-limiting regime map of the sodium caseinate powder is presented in Table 7. Fig. 5a shows that floating was the dominant rate-limiting regime up to $400 \mathrm{rpm}$ at $20^{\circ} \mathrm{C}$. A stronger vortex developed at $500 \mathrm{rpm}$ and more powder submerged into the water but formed many dispersed clumps, thus clumping became the rate-limiting regime. Even at the highest speed of $750 \mathrm{rpm}$, powder

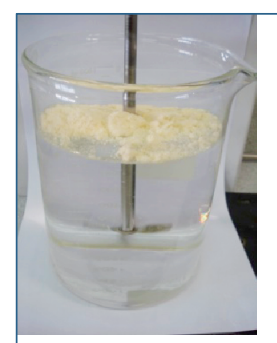

(a) $200 \mathrm{rpm} 60 \mathrm{~s}$ $20^{\circ} \mathrm{C}$

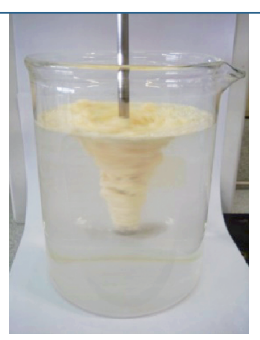

(b) $600 \mathrm{rpm} \mathrm{15s}$ $20^{\circ} \mathrm{C}$

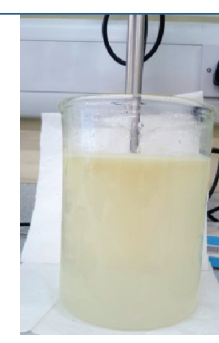

(c) $200 \mathrm{rpm} 60 \mathrm{~s}$ $7^{\circ} \mathrm{C}$
Fig. 4 Pictures from rate limiting regime mapping for high fat powder.

Table 7 Rate-limiting regime map for sodium caseinate powder

\begin{tabular}{|c|c|c|c|}
\hline $\begin{array}{c}\text { Speed } \\
(\mathrm{rpm})\end{array}$ & $20^{\circ} \mathrm{C}$ & $50{ }^{\circ} \mathrm{C}$ & $70^{\circ} \mathrm{C}$ \\
\hline 100 & \multirow{3}{*}{$\begin{array}{c}\text { floating } \\
\text { (decreased with } \\
\text { agitation) }\end{array}$} & \multirow{3}{*}{ floating } & \multirow{5}{*}{ floating } \\
\hline 200 & & & \\
\hline 300 & & & \\
\hline 400 & \multirow{2}{*}{$\begin{array}{l}\text { some floating } \\
+ \text { clumps in } \\
\text { dispersion }\end{array}$} & \multirow{2}{*}{$\begin{array}{l}\text { some floating } \\
+ \text { smaller clumps } \\
\quad \text { in dispersion }\end{array}$} & \\
\hline 500 & & & \\
\hline 600 & \multirow{3}{*}{$\begin{array}{l}\text { big clumps in } \\
\text { dispersion }\end{array}$} & \multirow{3}{*}{$\begin{array}{l}\text { some floating } \\
\text { + big clumps in } \\
\text { dispersion }\end{array}$} & $\begin{array}{l}\text { floating + } \\
\text { clumping }\end{array}$ \\
\hline 700 & & & big clumps on \\
\hline 750 & & & dispersion \\
\hline
\end{tabular}




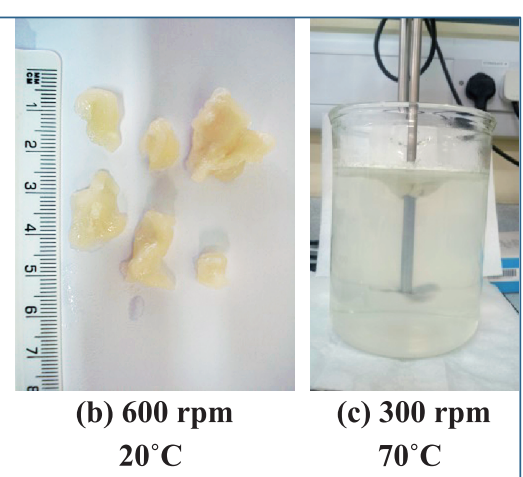

Fig. 5 Pictures from rate limiting regime mapping for sodium caseinate powder at 60 seconds.

clumps remained in dispersion. Many of the powder clumps were large in size (Fig. 5b) and the surface had a strong skin or film with dry powder inside that greatly impeded waters ability to penetrate into the bulk. Furthermore, the surface skin of the sodium caseinate was noticeably much stronger than skins developed on other poor wetting powders. Consequently, sodium caseinate powder clumps proved difficult to disrupt by the agitation. At higher temperatures, especially at $70{ }^{\circ} \mathrm{C}$, floating was more persistent and the powder dispersed more slowly, as illustrated by comparing Fig. 5a \& c. Clumping appeared to become more severe at higher temperatures with larger and stronger clumps being formed.

The most complex behavior was displayed by the flour powder. Both sedimentation and floating were observed up to $300 \mathrm{rpm}$ at all temperatures. Floating was more dominant at lower speed, but even at $100 \mathrm{rpm}$, some lumps of powder would sink to the bottom and this would increase with higher speed. As the vortex became stronger at 400 and $500 \mathrm{rpm}$, floating disappeared and the rate-limiting regime was due to clumps either becoming dispersed in the water or sinking to the bottom. Sedimentation ceased at 600 and $700 \mathrm{rpm}$, and rate-limitation was due to clumps in suspension. The major impact of temperature was on clumping. There was the least amount of clumping at $50{ }^{\circ} \mathrm{C}$ while there were more clumping and larger clumps formed at 20 and $70{ }^{\circ} \mathrm{C}$.

Overall, poor wetting powders tend to display floating and clumping behaviours. Many of the reasons for clumping are the same as those for floating, that is, hydrophobic surfaces and slimy skin or film formation. In stirred systems, wettability may be a rate-limiting step whereby powder clumping may occur on the surface and when submerged, and the agitator may have difficulty and take significant amount of time to sink and break up the clumps. Some of the poor wetting powders, most noticeably, sodium caseinate, flour and chocolate, developed noticeable slimy skins/films at the powder/water interface at $20^{\circ} \mathrm{C}$, which would further inhibit water penetration.
The strength of these films could make the clumps more resistant to disruption by the agitation system, and make it more difficult to disperse the powder residing within the clumps. Consequently, the next section of this work examined the film strength developed by the powders tested and how it is influenced by temperature.

\subsection{Film strength at powder/water interface}

The SMP is an easy wetting powder but did show a measurable film strength of $70 \mathrm{mN}$ at $20^{\circ} \mathrm{C}$ at $1 \mathrm{~min}$, as illustrated in Fig. 3b. There were no other measurements as SMP had wetted at all the other conditions. The chocolate powder and high fat powders were poor wetting powders at $20^{\circ} \mathrm{C}$, however their film strengths were low with $80 \mathrm{mN}$ at 1 and 20 minutes for chocolate and negligible strength for the high fat at all contact times. Consequently, strong film formation was not a major impediment to the wetting of these powders.

The sodium caseinate, MPI and flour powders all displayed measurable film strengths. These are presented in Table 8 as a function of time and temperature. They all showed similar film strengths of around 150 to $200 \mathrm{mN}$

Table 8 Film strength $(\mathrm{mN})$ of sodium caseinate, MPI and flour

\begin{tabular}{lccc}
\hline powder & $20{ }^{\circ} \mathrm{C}$ & $50{ }^{\circ} \mathrm{C}$ & $70{ }^{\circ} \mathrm{C}$ \\
\hline 13 min & 180 & $\frac{\text { Sodium caseinate }}{1}$ & 170 \\
$20 \mathrm{~min}$ & 200 & 860 & 900 \\
$1 \mathrm{~min}$ & 0 & MPI & \\
$20 \mathrm{~min}$ & 160 & 380 & 160 \\
$1 \mathrm{~min}$ & 200 & $\underline{\text { Flour }}$ & \\
$20 \mathrm{~min}$ & 220 & 410 & 170 \\
\hline
\end{tabular}

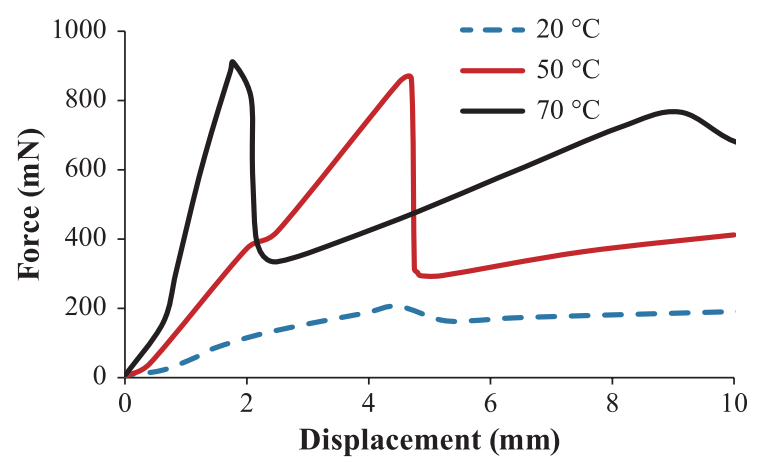

Fig. 6 Effect of temperature on film strength of sodium caseinate at 20 minutes contact time. 
aulfer dife minute contact time, irrespective of temperature, except for the MPI which showed negligible strength at $20^{\circ} \mathrm{C}$ although this did increase to $160 \mathrm{mN}$ after 20 minutes. However, increasing the temperature to 50 and $70{ }^{\circ} \mathrm{C}$ had a major impact on film strength at the longer exposure time of 20 minutes, especially for the caseinate as illustrated in Fig. 6. The caseinate displayed the strongest film strength, which concurs with that visually observed in the rate-limiting regime mapping. Consequently, these results suggest that the caseinate has a propensity to develop very strong films at these higher temperatures, especially when the powder film is exposed for longer time. The MPI and flour showed similar behaviour to caseinate at higher temperatures but the film strengths were not as strong.

\section{Conclusions}

In this study, composition was a major cause of poor wettability due to either higher fat or high milk protein contents, making the powder surfaces hydrophobic. Furthermore, the low apparent densities of the high fat and MPI powders may contribute to their poor wettability and their tendency to float. The formation of a slimy skin or film at the powder/water interface may contribute to poor wettability where water penetration into the bulk is greatly impeded. This enhances both floating and clump formation.

Vortexing in a stirred tank greatly improved wetting of even very poor wetting powders by rapidly submerging powder into the water and disruption of clumps by the action of the impeller. However, the formation of strong films by some powders, such as sodium caseinate, may result in the formation of clumps with strong skins that are difficult to disrupt and thus impede powder dispersion. Force-displacement testing can be applied to assess the susceptibility of powders to clumping and strong skin formation by measuring the strength of films formed at powder/water interfaces.

Temperature had a varied impact on the wettability of the poor wetting powders. Increasing temperature greatly improved the wetting and rehydration abilities of the chocolate and high fat powders. On the other hand, it reduced the wettability of the caseinate and MPI powders, which in-part is due to higher temperatures producing stronger films that impede the penetration of water into the bulk.

\section{References}

Barbosa-Canovas G.V., Ortega-Rivas E., Juliano P., Yan H., Bulk properties, in: Food Powders: Physical Properties,
Processing, and Functionality, Kluwer Academic/Plenum Publishers, New York, 2005.

Crowley S.V., Desautel B., Gazi I., Kelly A.L., Huppertz T., O’Mahony J.A., Rehydration characteristics of milk protein concentrate powders, J. Food Engineering, 149 (2015) 105113.

Dupas J., Verneuil E., Ramaioli M., Forny L., Talini L., Lequeux F., Dynamic wetting on a thin film of soluble polymer: Effects of nonlinearities in the sorption isotherm, Langmuir, 29 (2013) 12572-12578.

Fennema O., Ed, Food Chemistry, Marcel Dekker, New York, 1985.

Fitzpatrick J.J., Cuthbert R., Effect of temperature on the reconstitution of milk powder to high solids content in a stirredtank, Milchwissenschaft, 59 (2004) 55-58.

Fitzpatrick J.J., van Lauwe A., Coursol M., O'Brien A., Fitzpatrick K.L., Ji J., Miao S., Investigation of the rehydration behaviour of food powders by comparing the behaviour of twelve powders with different properties, Powder Technology, 297 (2016) 340-348.

Gaiani C., Schuck P., Scher S., Desobry S., Banon S., Dairy powder rehydration: Influence of protein state, incorporation mode, and agglomeration, J. Dairy Science, 90 (2007) 570-581.

Gaiani C., Schuck P., Scher S., Desobry S., Banon S., Use of a turbidity sensor to determine dairy powder rehydration properties, Powder Technology, 190 (2009) 2-5.

Gaiani C., Morand M., Sanchez C., Arab Tehrany E., Jacquot M., Schuck P., Jeantet R., Scher S., How surface composition of high milk protein powders is influenced by spray drying temperature, Colloids and Surfaces B: Biointerfaces, 75 (2010) 377-384.

IDF, International IDF Standard 87: 1979. International Dairy Federation, Brussels, Belgium, 1979.

Jeantet R., Schuck P., Six T., Andre C., Delaplace G., The influence of stirring speed, temperature and solid concentration on the rehydration time of micellar casein powder, Dairy Science and Technology, 90 (2010) 225-236.

Ji J., Fitzpatrick J., Cronin K., Maguire P., Zhang H., Miao S., Rehydration behaviours of high protein dairy powders: The influence of agglomeration on wettability, dispersibility and solubility, Food Hydrocolloids, 58 (2016) 194-203.

Kim E.H.J., Chen X.D., Pearce D., Surface characterization of four industrial spray-dried powders in relation to chemical composition, structure and wetting property, Colloids and Surfaces B: Biointerfaces, 26 (2002) 197-212.

McCarthy O.J., Physical characteristics of milk fat and milk fat based products, in: Fox P.F., McSweeney P.L.H. (Eds), Advanced Dairy Chemistry, vol. 2 Lipids. Springer, New York, 2006, pp. 725-778.

Mitchell W.R., Forny L., Althaus T.O., Niederreiter G., Palzer S., Hounslow M.J., Salman A.D., Mapping the rate-limiting regimes of food powder reconstitution in a standard mixing vessel, Powder Technology, 270 (2015) 520-527.

Porowska A., Gianfrancesco A., Fries L., Dosta M., Palzer S., Heinrich S., Influence of feed composition and drying parameters on surface composition of a spray dried multicomponent particle, Drying Technology, 33 (2015) 1911- 
Ponter N.N., Food Science, AVI publishing Company, Connecticut, 1986.

Richard B., Le Page J.F., Schuck P., Andre C., Jeantet R., Delaplace G., Towards a better control of dairy powder rehydration processes. International Dairy Journal, 31 (2013) 18-28.

Schober C., Fitzpatrick J.J., Effect of vortex formation on pow- der sinkability for reconstituting milk powders in water to high solids content in a stirred-tank, J. Food Engineering, 71 (2005) 1-8.

Schubert H., Instantization of powdered food products, International Chemical Engineering, 33 (1993) 28-44.

Washburn E.W., The dynamics of capillary flow, Physical Review, 17 (1921) 273-283.

\section{Author's short biography}
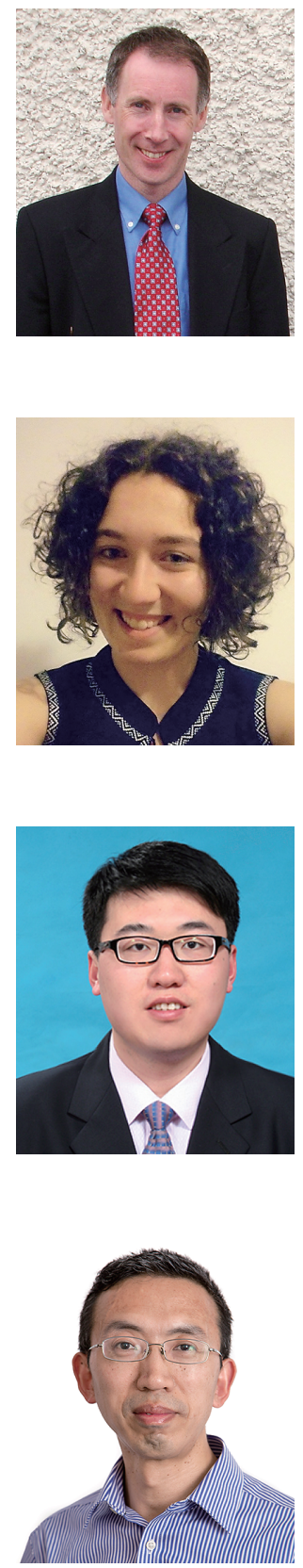

\section{John J. Fitzpatrick}

Dr. John Fitzpatrick is a senior lecturer in Process \& Chemical Engineering. His research interests are in food particle \& powder technology and sustainability \& environmental protection. He has been involved in research projects in powder flowability and caking; protein precipitation and sugar crystallisation; dry powder mixing and rehydration of food powders.

\section{Justine Salmon}

Justine Salmon is a student in food science at the "Agrocampus Ouest" food engineering school in Rennes (France). She undertakes her studies through an apprenticeship and works at Entremont in the production of dairy powders. As part of her studies, she carried out a work placement in University College Cork and participated in a research project on the rehydration behaviour of poor wetting powders.

\section{Junfu Ji}

Junfu Ji is currently a Walsh fellow in Teagasc Food Research Centre Moorepark and also a PhD candidate in Process \& Chemical Engineering, University College Cork. His research focuses on dairy powder agglomeration processes (fluidised bed and high shear mixer granulation) and the rehydration behaviour, physical \& structural properties and flowability of dairy powders and their agglomerates.

\section{Song Miao}

Dr. Song Miao is Senior Research Officer in Food Technology at Teagasc Food Research Centre Moorepark. His current research programme focuses on development of novel food structures for functional delivery, water structuring and powder technologies. His research interests cover dehydration and granulation, foods structural and textural design, powder technology, state transition and phase transition in foods, encapsulation of functional food ingredients, stabilization of probiotics and dairy ingredients. 